\begin{tabular}{|c|c|c|}
\hline & Int.J.Curr.Microbiol.App.Sci (2021) 10(08): 358-364 & \\
\hline & $\begin{array}{l}\text { International Journal of Current Microbiology and Applied Sciences } \\
\text { ISSN: 2319-7706 Volume } \mathbf{1 0} \text { Number } 08 \text { (2021) } \\
\text { Journal homepage: } \underline{\text { http://www.ijcmas.com }}\end{array}$ & $\begin{array}{l}9 \\
-9\end{array}$ \\
\hline $\begin{array}{l}\text { EXCELLENT } \\
\text { PUBLISHERS }\end{array}$ & & wuww.ijcmas.com \\
\hline
\end{tabular}

\title{
Micro Nutrient to Enhance Yield in Banana Cultivation
}

\author{
K. Dhanalakshmi ${ }^{1}$, K. Chitra $^{2 *}$ and K. Karthikeyani Vijayakumari ${ }^{3}$ \\ ${ }^{1}$ Department of Horticulture, KVK, Vamban, India \\ ${ }^{2}$ Department of Plant pathology, TRRI, Aduthurai, Tamil Nadu Agricultural University, \\ Coimbatore, India \\ ${ }^{3}$ Government Arts and Science College, Pudukkottai, India \\ *Corresponding author
}

\section{A B S T R A C T}

Keywords

Vamban, lemon juice, shampoo pocket, foliar application, Banana

Article Info

Accepted:

20 July 2021

Available Online:

10 August 2021
Banana is a globally important fruit crop with the annual production of 97.5 million tons. India is in $2^{\text {nd }}$ after China with the annual production of 16.91 million tons from 490.70 thousands hectares. Banana contributes $32 \%$ to the total fruit production of the country. Maharastra, Tamil Nadu, Kerala, Karnataka, Gujarat, Anthra Pradesh and Assam are the major state growing banana. Micronutrient disorders are most common in Tamilnadu. KVK, Vamban, Pudukkottai conducted Front Line Demonstration on Micro Nutrient mixture IIHR Banana special with the following objectives. To assess the knowledge level of farmers for the adoption of Banana special for markeable bunch, to assess the increased yield in Banana by adoption of Banana special, to assess constrains faced by farmers. Mix 50 grams of Banana special along with one lemon juice and 1 shampoo pocket in 10 liters of water are added and mix thoroughly before spraying. Drenching the solution of $250 \mathrm{ml} /$ plant after of 15 days of plantation in case of tissue culture plants. Start from 4 months of plantation once in 30 days continues up to 8 months as foliar application. Last two sprays done both on bunch and leaves 30 days and 60 days after bunch emergence. B:C ratio of 3.7 at demonstrated farmer's field than the check plot 3.4. From the study it was revealed that price of fresh bunches fetches minimum price than the processed and value added products. Therefore, the farmers need to be encouraged to take up processing by themselves by giving them subsidy or loan for establishing the small scale processing units.

\section{Introduction}

KVK, Vamban, Pudukkottai conducted Front Line Demonstration on Micro Nutrient mixture IIHR Banana special during 2016-17 and 2017-18 to increase the marketable bunch especially in Banana. In this context, the study has been conducted in Tiruvaranklam block of Pudukkottai district.

Micro nutrients or trace elements are essential are essential for plant growth bt it is needed in very small quantity for the plant system. Banana special is crop specific micronutrient 
formulation technology through foliar application exclusive for higher yield in banana crop up to $20 \%$. $6 \mathrm{~kg}$ of Banana Special recommended for an acre as a foliar application recommended by IIHR. Mix 50 grams of Banana special along with one lemon juice and 1 shampoo pocket in 10 liters of water are added and mix thoroughly before spraying. Drenching the solution of $250 \mathrm{ml}$ /plant after of 15 days of plantation in case of tissue culture plants. Start from 4 months of plantation once in 30 days continues up to 8 months as foliar application. Last two sprays done both on bunch and leaves 30 days and 60 days after bunch emergence. Spray should be done preferably $6 \mathrm{am}$ to $11 \mathrm{am}$ and $4 \mathrm{pm}$ to $6.30 \mathrm{pm}$ and spray should be done mainly $60-$ $70 \%$ on lower surface and $30 \%$ on upper surface.

\section{Materials and Methods}

Demonstration of Banana special was carried out by Krishi Vigyan Kendra in Thiruvarankulam block of Pudukkottai district in order to enhance the production potential of exportable bnch of banana. Out of twelve blocks in Pudukkottai district, two blocks namely, Gandarvakottai and Thirvaranklam were selected to conduct this study. A total of ten farmers from these blocks were selected randomly for this study purpose. A wellstructured interview schedule was used to collect data for documenting of Banana Special on productivity with marketable bunch.

\section{Indicator studies}

\section{Step 1: Development of Indicators}

Conducting demonstration is one of the important component for the dissemination of any Agricultural technologies. KVK decided to work on "Banana Special" for the better marketable bunches.
KVK decided to introduce the concept called Front Line Demonstration on Banana special in participatory approach method. In a participatory manner KVK involved for conducting the demonstration. Based on the study the following indicators were drafted.

Indicator - 1: Experience in Banana cultivation

Indicator - 2: Knowledge in adoption of technologies

Indicator - 3: Foliar application of micro nutrient

Indicator - 4: Adoption and time of Banana special

Indicator - 5: Socio-economic Profile of the Sample Respondents

Indicator - 6: Cost Utilization Pattern in banana Cultivation

Indicator - 7: Input Utilization Pattern in Banana Cultivation

Indicator - 8: Labour Utilization Pattern in Banana Cultivation

Indicator - 9: Spread of technology

Indicator - 10: Constraints faced by farmers

Indicator -11 : Cost details and Benefit Cost Ratio with yield

The data collected from the farmers are consolidated and furnished as below

\section{Indicator - 1 \& 2: Experience and knowledge in Banana cultivation}

It was noticed that, all farmers are practicing the Banana cultivation as a primary work. 
All the farmers are enrolled their name in Banana cultivation. All the farmers cultivating Banana in their land. But the technology about Banana cultivation, and other quality improving techniques are not having sufficient knowledge.

\section{Indicator - 3: Foliar application of Micro Nutrient}

The study revealed that, farmers are not applying recommended doss or soil based micro nutrients application, since they are not exposed on the importance of micro nutrients in enhancing in banana productivity and the marketable bunch. Banana special is a foliar micronutrient produced by IIHR Bengaluru for enhancing the productivity.

\section{Indicator- 4: Adoption and time of Banana} special application

Though the technology was helpful for increasing the productivity, the study shows that, the Banana special application is promote by Krishi Vigyan Kenra, Pudukkottai. farmers applied the banana special during the morning time or in the evening time which results in enhanced the efficiency of the micro nutrient uptake of the crop.

\section{Indicator - 7: Input Utilization Pattern in Banana Cultivation}

The resource poor farmers in the study area don $t$ use any special horticultural techniques like mulching, drip irrigation and pinching. This might be due to lack of technical knowledge. In this area, both open irrigation and drip irrigation type of farming situations are existed. They are unaware about the practice of pruning, foliar application and plant protection. They don't use of any organic input like organic manure, bio fertilizer, pesticides etc which can boost their yield. Which ultimately reduces the fingure yield. It was revealed from the study that majority of farmers were not applying FYM or organic manure. Hence, there is a need to create awareness in the farmers about the use of organic manures, micro nutrient application.

\section{Indicator - 8: Labour Utilization Pattern in Banana Cultivation}

\section{Indicator - 9: Spread of technology}

The interesting fact noted that the technology was spread through the KVK, Vamban, Pudukkottai.

Indicator - 5: Socio-economic Profile of the Sample Respondents Table.1 Questionnaire Response

\begin{tabular}{|l|c|c|}
\hline S.No. & Question & Per cent \\
\hline $\mathbf{1 .}$ & Knowledge about KVK & $\mathbf{8 0}$ \\
\hline $\mathbf{2 .}$ & Experience in Banana cultivation & $15-45$ Years \\
\hline $\mathbf{3 .}$ & Knowledge in adoption of technologies & 15 \\
\hline $\mathbf{4 .}$ & Knowledge on Micro Nutrient & 15 \\
\hline $\mathbf{5 .}$ & Knowledge about Banana special & 10 \\
\hline $\mathbf{6 .}$ & Application of Banana special & 10 \\
\hline $\mathbf{7 .}$ & Knowledge about Time of application & 95 \\
\hline
\end{tabular}


Table.2 The socio-economic profile of the Banana growers of the study area.

\begin{tabular}{|c|c|c|c|}
\hline S. No & Basic details & Variations & No.of person \\
\hline 1. & Age group of the farmers & $\begin{array}{l}40-50 \\
30-40 \\
20-30\end{array}$ & $\begin{array}{l}6 \\
3 \\
1\end{array}$ \\
\hline 2. & Education & $\begin{array}{c}10 \\
12 \\
\text { Degree }\end{array}$ & $\begin{array}{l}0 \\
7 \\
3\end{array}$ \\
\hline 3. & Family Type & $\begin{array}{l}\text { Join family } \\
\text { Single }\end{array}$ & $\begin{array}{l}6 \\
4\end{array}$ \\
\hline 4. & Family size & $\begin{array}{l}\text { Small } \\
\text { Medium } \\
\text { Big }\end{array}$ & $\begin{array}{l}1 \\
6 \\
3\end{array}$ \\
\hline 5. & Agriculture as occupation & Primary & 10 \\
\hline 6. & Average Annual Income & 69,000 & 10 \\
\hline 7. & $\begin{array}{c}\text { Average area under Banana } \\
\text { cultivation }\end{array}$ & 1 acre & 10 \\
\hline 8. & Growing pattern & $\begin{array}{l}\text { Irrigated } \\
\text { Rain fed }\end{array}$ & $\begin{array}{c}10 \\
0\end{array}$ \\
\hline 9. & Soil pattern & $\begin{array}{c}\text { Red } \\
\text { Sandy loam }\end{array}$ & $\begin{array}{l}3 \\
7\end{array}$ \\
\hline
\end{tabular}

Indicator.6 Cost Utilization Pattern in banana Cultivation

\begin{tabular}{|c|c|c|}
\hline S. No & Particulars & Rs \\
\hline $\mathbf{1 .}$ & Field preparation & 6000 \\
\hline $\mathbf{2 .}$ & Nursery and planting / sowing & 8000 \\
\hline $\mathbf{3 .}$ & Weeding & 8000 \\
\hline $\mathbf{4 .}$ & Plant protection & 10000 \\
\hline $\mathbf{5 .}$ & Fertilizers & 10000 \\
\hline $\mathbf{6 .}$ & Wages & 6000 \\
\hline $\mathbf{7 .}$ & Staking, transport \& other expenses & 80000 \\
\hline & Total & $\mathbf{5 6 0 0 0}$ \\
\hline
\end{tabular}

Table.3 Labour Utilization Pattern in Banana Cultivation

\begin{tabular}{|c|c|c|c|}
\hline S.No & Description & Man x days & Total man power \\
\hline $\mathbf{1 .}$ & Land preparation & 5 & 5 \\
\hline $\mathbf{2 .}$ & Ploughing (by bullocks) & 10 & 20 \\
\hline $\mathbf{3 .}$ & Mulch collection & $12 \times 2$ days & 24 \\
\hline $\mathbf{4 .}$ & Mulching & $10 \times 1$ day & 10 \\
\hline $\mathbf{5 .}$ & Sowing & $10 \times 3$ days & 30 \\
\hline $\mathbf{6 .}$ & Weeding & $5 \times 2$ days & 10 \\
\hline $\mathbf{7 .}$ & Special and Inter cultural operation & $2 \times 5$ days & 10 \\
\hline $\mathbf{8 .}$ & Harvesting (plucking) & $5 \times 20$ & 100 \\
\hline $\mathbf{9 .}$ & Grading and packing & $1 \times 20$ days & 20 \\
\hline
\end{tabular}


Table.4 Constraints faced by banana growers in the study area

\begin{tabular}{|c|c|c|}
\hline S. No. & Particulars & Score \\
\hline $\mathbf{1 .}$ & High cost of labour & I \\
\hline $\mathbf{2 .}$ & Personal obligation with Traders & II \\
\hline $\mathbf{3 .}$ & Financial weakness & III \\
\hline $\mathbf{4 .}$ & Lack of technical knowledge & IV \\
\hline $\mathbf{5 .}$ & Lack of storage facilities & V \\
\hline $\mathbf{6 .}$ & Low productivity & VI \\
\hline $\mathbf{7 .}$ & Non availability of quality seed & VII \\
\hline $\mathbf{8 .}$ & Inadequate market information & VIII \\
\hline
\end{tabular}

Table.5 Check plot details

\begin{tabular}{|c|c|c|c|c|c|c|c|}
\hline Farmer & $\begin{array}{c}\text { Bunch } \\
\text { weight } \\
\text { (kg) }\end{array}$ & $\begin{array}{c}\text { Nmber of } \\
\text { marketable } \\
\text { Bnch/ha }\end{array}$ & $\begin{array}{c}\text { Yield } \\
\text { (quintal) }\end{array}$ & $\begin{array}{c}\text { Gross } \\
\text { Cost }\end{array}$ & $\begin{array}{c}\text { Gross } \\
\text { Cost }\end{array}$ & $\begin{array}{c}\text { Net } \\
\text { Return }\end{array}$ & $\begin{array}{c}\text { Benefit } \\
\text { Cost } \\
\text { Ratio }\end{array}$ \\
\hline $\mathbf{1}$ & 15.2 & 2015 & 380 & 113000 & 403000 & 290000 & 3.6 \\
\hline $\mathbf{2}$ & 19.6 & 1879 & 368 & 113000 & 375800 & 262800 & 3.3 \\
\hline $\mathbf{3}$ & 20.4 & 1887 & 385 & 113500 & 377400 & 263900 & 3.3 \\
\hline $\mathbf{4}$ & 13.8 & 1990 & 275 & 113000 & 398000 & 285000 & 3.5 \\
\hline $\mathbf{5}$ & 18.3 & 1990 & 364 & 113000 & 398000 & 285000 & 3.5 \\
\hline $\mathbf{6}$ & 19.2 & 1890 & 363 & 103000 & 378000 & 275000 & 3.7 \\
\hline $\mathbf{7}$ & 21.9 & 1902 & 417 & 113000 & 380400 & 267400 & 3.4 \\
\hline $\mathbf{8}$ & 20.8 & 1800 & 418 & 115000 & 360000 & 245000 & 3.1 \\
\hline $\mathbf{9}$ & 14.3 & 1890 & 270 & 117000 & 378000 & 261000 & 3.2 \\
\hline $\mathbf{1 0}$ & 15.8 & 1997 & 316 & 116500 & 399400 & 282900 & 3.4 \\
\hline Average & $\mathbf{1 7 . 9}$ & $\mathbf{1 9 2 4 . 0}$ & $\mathbf{3 5 5 . 5}$ & $\mathbf{1 1 3 0 0 0 . 0}$ & $\mathbf{3 8 4 8 0 0 . 0}$ & $\mathbf{2 7 1 8 0 0 . 0}$ & $\mathbf{3 . 4}$ \\
\hline
\end{tabular}

Table.6 Demonstrated plot details

\begin{tabular}{|c|c|c|c|c|c|c|c|}
\hline Farmer & $\begin{array}{c}\text { Bunch } \\
\text { weight } \\
\text { (kg) }\end{array}$ & $\begin{array}{c}\text { Nmber of } \\
\text { marketable } \\
\text { Bnch/ha }\end{array}$ & $\begin{array}{c}\text { Yield } \\
\text { (quintal) }\end{array}$ & $\begin{array}{c}\text { Gross } \\
\text { Cost }\end{array}$ & $\begin{array}{c}\text { Gross } \\
\text { Cost }\end{array}$ & $\begin{array}{c}\text { Net } \\
\text { Return }\end{array}$ & $\begin{array}{c}\text { Benefit } \\
\text { Cost } \\
\text { Ratio }\end{array}$ \\
\hline $\mathbf{1}$ & 22.5 & 2100 & 420 & 110000 & 420000 & 310000 & 3.82 \\
\hline $\mathbf{2}$ & 24.5 & 2076 & 450 & 109000 & 415200 & 306200 & 3.81 \\
\hline $\mathbf{3}$ & 21.3 & 2150 & 458 & 110500 & 430000 & 319500 & 3.89 \\
\hline $\mathbf{4}$ & 27.6 & 2168 & 430 & 113000 & 433600 & 320600 & 3.84 \\
\hline $\mathbf{5}$ & 22.8 & 2090 & 477 & 111200 & 418000 & 306800 & 3.76 \\
\hline $\mathbf{6}$ & 29.6 & 1970 & 380 & 113000 & 394000 & 281000 & 3.49 \\
\hline $\mathbf{7}$ & 24.7 & 2050 & 460 & 110000 & 410000 & 300000 & 3.73 \\
\hline $\mathbf{8}$ & 28.9 & 1990 & 440 & 150000 & 398000 & 248000 & 2.65 \\
\hline $\mathbf{9}$ & 29.5 & 2153 & 450 & 112000 & 430600 & 318600 & 3.84 \\
\hline $\mathbf{1 0}$ & 22.6 & 2200 & 450 & 115000 & 440000 & 325000 & 3.83 \\
\hline Average & $\mathbf{2 5 . 4}$ & $\mathbf{2 0 9 4 . 7}$ & $\mathbf{4 4 1}$ & $\mathbf{1 1 5 3 7 0}$ & $\mathbf{4 1 8 9 4 0}$ & $\mathbf{3 0 3 5 7 0}$ & $\mathbf{3 . 7}$ \\
\hline
\end{tabular}


Fig.1 Yield, Net return and BCR for Treated and Check of Banana cultivation

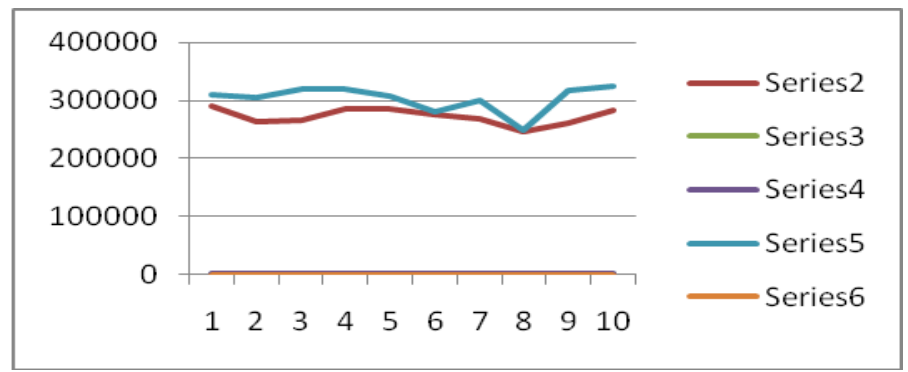

Indicator- 10: Constraints Faced in Banana Cultivation in the Study area

The major constraints faced in cultivation of banana in the study area are presented in Table 6 . The study revealed that the major problems faced by the growers in production are high cost of labour, non-availability of quality seed, lack of technical knowledge, financial obligation, inadequate market information and low productivity. The sample respondents ranked high cost of labour as the greatest constraint with a Garrett score of 76.40 .

The problems ranked at second, third and fourth place were personal obligation with traders, financial weakness, lack of technical knowledge and lack of storage facilities with Garrett scores of 71.24,70.20,56.90 and 48.03 respectively.

\section{Indicator - 11: Cost details and Benefit Cost Ratio with yield}

\section{Cost of Cultivation}

The study shows (Table: 5 and 6) that, the Cost of Cultivation was increased in banana special applied field in terms of Rs. 115370 /ha (Singh Verma 2001) when compared to the existing farming practices 113000 . By adopting this technology $24 \%$ yield increased was recorded. The average incremental benefit reaped from the banana special was recorded Rs. 303570/ha Umagowri, Chandrasekaran, 2011.
The marketable quantity is high in treated area. It indicates that the Micro Nutrients directly or indirectly influencing the marketable bunches.

\section{Gross cost and Net Return (Table 5and 6)}

In control the maximum Gross cost recorded the 1,17,000 and the minimum Gross Cost value of 1,03,000 was recorded and the average Gross Cost is 1,13,000. For demonstrated method the maximum Gross Cost 1,50,000 was recorded and the minimum Gross Cost recorded the value of 1,09,000. Regarding the Net Return in demonstrated plot the maximum was recorded 3,25,000 and the average net return was $3,03,570$. In check the minimum Net Return recorded 2,45,000 and the average net return was $2,71,800$. For demonstrated method the average net return was 303570

\section{Benefit Cost Ratio (Table 5 and 6)}

The benefit cost ratio for demonstrated method was 3.7 for check it was 3.4.

Banana is one of the most important fruit crops grown in Pudukkottai district; however the productivity is continuously decreasing year by year. Thus, there is need to increase the productivity to fulfill the domestic requirement, commercial marketting and for export. Banana cultivation is capital intensive and needs more investment. It has been observed that technological interventions 
pairing and pralinage (Almeida et.al, 2018), desuckering, propping, denevaling, foliar application of micro nutrients, bunch covering, soil application of bio control agent, crop rotation, mulching, and plant protection measures increased the bunch weight, there by yield is increased (Umagowri and Chandrasekaran, 2011) by 20 per cent with a $\mathrm{B}: \mathrm{C}$ ratio of 3.7 at demonstrated farmer's field than the check plot 3.4. To enhance the productivity, eco friendly production technologies among the farming community are the need of the hour. The indigenous technical knowledge acquired by the farmers need to be tested and refined with the modern techniques of crop cultivation. Efforts should be made in the selection and production of improved cultivars with technological interventions local cultivars having high bunch weight, resistant to pest and diseases (Guayo, et al., 2017) and time of irrigation, training on application of organic inputs, botanical formulations and biocontrol agents (Akila, R., Rajendran, 2011) should be followed. From the study it was revealed that price of fresh bunches fetches minimum price than the processed and value added products. Therefore, the farmers need to be encouraged to take up processing by themselves by giving them subsidy and/or loan for establishing the small scale processing units. Government should support.

\section{References}

Akila, R., Rajendran, L., Harish, S., Saveetha, K., Raguchander, T., and Samiyappan, R. (2011). Combined application of botanical formulations and biocontrol agents for the management of Fusarium oxysporum f. sp. cubense (Foc) causing Fusarium wilt in banana. Biol. Contr. 57, 175-183. doi: 10.1016/j.biocontrol.2011.02.010

Almeida, N. O., Teixeira, R. A., Carneiro, F. A., Oliveira, C. M., de Ribeiro, V. A., Lobo Júnior, M., et al., (2018). Occurrence and correlations of nematodes, Fusarium oxysporum and edaphic factors on banana plantations. J. Phytopathol. 166, 1-8. doi: 10.1111/jph.12683

Guayo, J., Mostert, D., Fourrier-Jeandel, C., Cerf-Wendling, I., Hostachy, B., Viljoen, A., et al., (2017). Development of a hydrolysis probebased real-time assay for the detection of tropical strains of Fusarium oxysporum f. sp. cubense race 4. PLoS ONE 12:e0171767. doi: 10.1371/journal.pone.0171767

Umagowri M, Chandrasekaran M. An economic analysis of value chain of banana in Western Tamil Nadu. IUP Journal of Supply Chain Management.2011;7(3):66-80.

\section{How to cite this article:}

Dhanalakshmi, K., K. Chitra and Karthikeyani Vijayakumari, K. 2021. Micro Nutrient to Enhance Yield in Banana Cultivation. Int.J.Curr.Microbiol.App.Sci. 10(08): 358-364. doi: https://doi.org/10.20546/ijcmas.2021.1008.043 